\title{
Ryste eller riste?
}

Heter det rist flasken eller ryst flasken? Svar: Begge deler, men ryste brukes helst om følelser.

Riste og ryste er varianter av samme ord. De hadde opprinnelig samme betydning, men i moderne norsk er det blitt en forskjell. Riste brukes oftest i konkrete sammenhenger, dvs. om noe som beveges fort frem og tilbake, slik som i: Han ristet på hodet; de ristet ned eplene av treet; rist flasken godt før bruk. Ryste kan ha samme betydning, men blir i tillegg ofte brukt for å uttrykke følelser: Vi ble rystet da vi hørte om overfallet; boken var rystende lesing (1). Et skoleeksempel på riktig bruk av begge former er derfor: Det var en rystende opplevelse å bli ristet våken av politimannen (2).

I dag oppfattes nok ryste som noe talespråksfremmed og kanskje gammeldags. Mange vil av den grunn ikke bruke det (3). I Tidsskriftets nettutgave er ordet registrert brukt kun én gang: «Likevel er dette en medrivende bok, som har potensial til virkelig å ryste leserens verdensbilde» (4). Men det er flere eksempler på at riste brukes i ikke-konkret betydning, f.eks. «Far lærte meg at man må riste av seg nederlag og gå videre uten å dvele ved dem» (5) og «Den er også et forsøk på å riste av seg pasientrollen og uførhetsstemplet» (6).

Min erfaring er at legemidler ofte har påskriften ryste. Et søk på felleskatalogen.no bekrefter dette. Ryste lever her i beste velgående. Ordet gir ni treff på felleskatalogtekster og 54 på pakningsvedlegg. Tilsvarende tall for riste er 79 og 107. Samlet utgjør altså ryste $34 \%$. Samme mønster er det for ryst versus rist (36\%). Forfatteren André Bjerke (1918-85), som var riksmålsmann, argumenterte i 1960-årene for at det heter å riste flasken, men at formen ryste ennå kan «holde stand i apotekersproget» (2). Det gjelder visst altså fortsatt.

Substantivet av riste er risting: Ristingen på toget var en påkjenning; intens hoderisting, mens det å bli rystet kalles rystelse: Rystelsene var store under jordskjelvet; han pådro seg en hjernerystelse (1). Ryste er den tradisjonelle, dansk-norske formen (2) og finnes ikke i nynorsk. Der heter det ikke

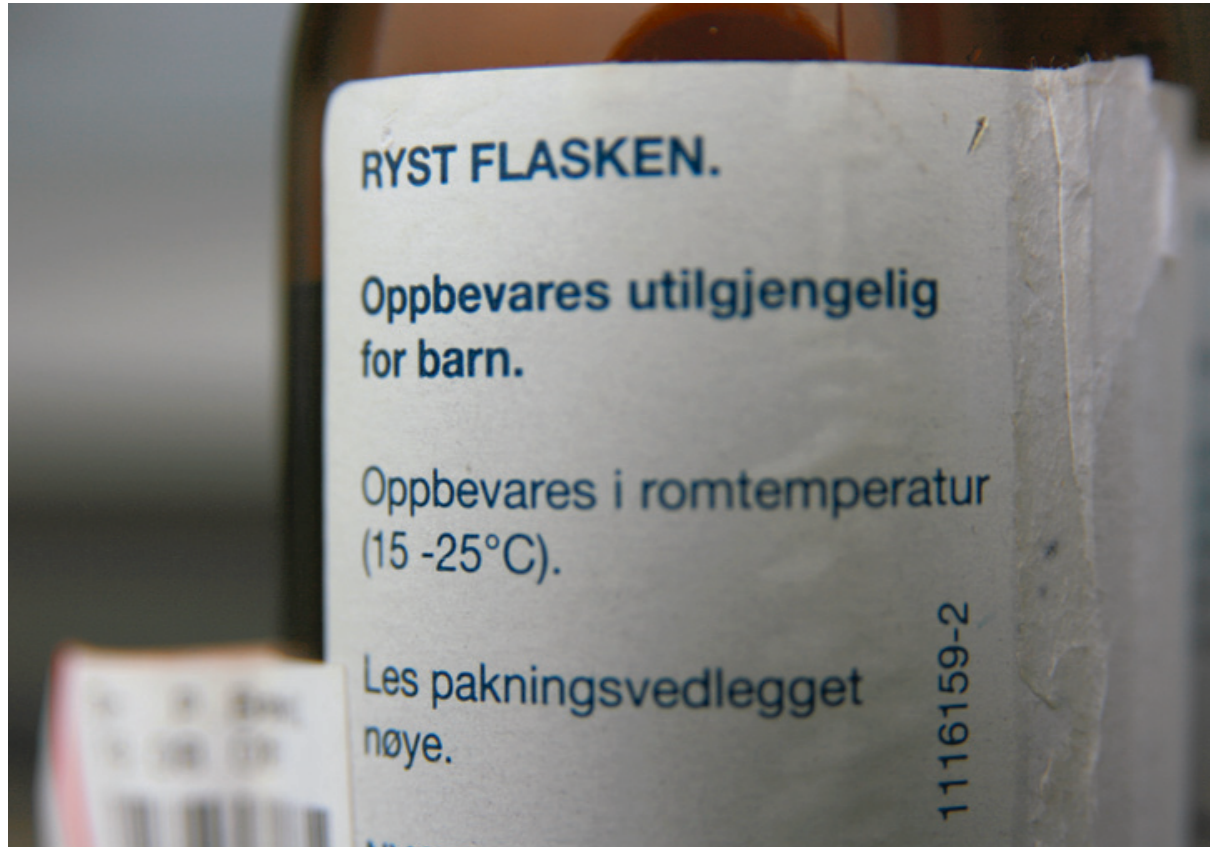

«Ryst flasken» står det fremdeles på mange etiketter. I eldre riksmål var «ryste» nærmest enerådende normalform, men $i$ «moderne sprogbruk har denne variant fått en avgrenset, figurlig betydning» (2), om det å bli oppskaket. Foto: Erlend Hem

hjernerystelse, men hjerneristing eller heileskaking (7). Ordparet ryste/riste har flere paralleller. I moderne norsk kan vi fortsatt ane en nyanseforskjell på kold/kald, rinne/ renne, sort/svart og syd/sør (8).

\section{Erlend Hem}

erlend.hem@medisin.uio.no

Erlend Hem (f. 1970) er dr.med. og assisterende sjefredaktør i Tidsskriftet.

\section{Litteratur}

1. Klouman S. Moro med ord: litt om ordenes vandringer, historie, slektskap og hemmeligheter. 2. utg. Oslo: Aschehoug, 2000: 264. www.nb.no/ $\mathrm{nbsok} / \mathrm{nb} / 38403 \mathrm{da0} 13 \mathrm{fece} 412 \mathrm{ba817109e4af53d?}$ index $=0 \# 265$ (22.4.2014).

2. Bjerke A. Hva er godt riksmål? Spørsmål og svar. 2. utg. Oslo: Riksmålsforbundet, 1967: 71. www.nb.no/nbsok/nb/3ce6006e6d3739dbcd441256 aa8c3e1e?index=11\#72 (22.4.2014).

3. Les spørsmål og svar fra oktober 2002. Bokklubben. www.bokklubben.no/SamboWeb/ side.do?dokld=76382 (22.4.2014).

4. Pihlstrøm L. Hvem tror du at hjernen din er? Anmeldelse av: Eagleman D. Incognito. Tidsskr Nor Legeforen 2013; 133: 1858.

5. Swensen E. Så sykler vi på Mjøsa. Tidsskr Nor Lægeforen 2006; 126: 1780-1.

6. Kirkengen AL. Åpent, men skjult. Anmeldelse av: Worsley AT. Kronisk. Tidsskr Nor Legeforen 2011: 131: 149-50.

7. Hjerneristing. I: Nynorskordboka. www.nob-ordbok.uio.no/perl/ordbok.cgi?OPP= hjerneristing\&nynorsk $=+\&$ ordbok=begge (22.4.2014).

8. Bjerke A. Hårdt mot hårdt. Oslo: Riksmålsforbundet, 1968: 60. www.nb.no/nbsok/nb/8d56bb9ac 5283 ecd082a9eb92e2efcee?index=9\#61 (22.4.2014)

Mottatt 22.4.2014 og godkjent 17.6. 2014. Redaktør: Marit Skaar Fjellhaug. 